\title{
ПАРАДИГМАТИЧЕСКИЕ ОТНОШЕНИЯ В ТЕРМИНОЛОГИИ ХОРЕОГРАФИЧЕСКОГО ИСКУССТВА
}

Кажан В. І., Калініна Р. П. Парадигматичні відношення в термінології хореографічного мистецтва.

У статті на матеріалі термінів хореографії розглядається явище синонімії й варіантності, полісемії та омонімії в межах досліджуваної групи лексики.

Ключові слова: термін, термінологія, синонімія, дублети, варіанти, полісемія, омонімія.

Кажан В. И., Калинина Р. П. Парадигматические отношения в терминологии хореографического искусства.

В статье рассматриваются явления синонимии и вариантности, полисемии и омонимии в терминологии хореографии.

Ключевые слова: термин, терминология, парадигматика, синонимы, варианты, дублеты, полисемия, омонимия.

Kazhan V. I., Kalinina R. P. Paradigmatical relations in he terminology of choreography.

The article deals with the phenomenon of synonymy and variation, polysemia and homonymy in the terminology of choreography.

Key words: term, terminology, paradigmatics, synonyms, variants, doubles, polysemia, homonymy.

Современная терминология хореографии - это незамкнутая, подвижная система наименований танцев, танцевальных движений, фигур, позиций, для которой характерны лексико-семантические взаимосвязи с лексикой общелитературного языка и в элементами других терминологий. Изучение парадигматических отношений в хореографической лексике имеет большое значение для решения общей проблемы термина, установления специфики терминологии хореографии как отдельного вида искусства.

С лингвистической точки зрения термины должны соответствовать в первую очередь принципам системности и нормативности. Важно обратить внимание на синонимические, полисемические и омонимические отношения, один из видов внутренних парадигматических связей терминологических единиц в исследуемой терминосистеме.

Существуют различные мнения относительно того, имеет ли место в терминологии синонимия. Одни языковеды считают, что терминам присущи синонимические отношения (например, В. П. Даниленко [4]), 
другие видят в этом проявление либо дублетности («в пределах научного контекста все синонимы (термины) - дублеты» [6, с. 87], либо же абсолютной синонимии (Л. А. Новиков считает абсолютные синонимы своеобразным пределом синонимии [8, с. 18], третьи относят к дублетам абсолютные синонимы как разнозначные «...могут наблюдаться в языковой системе и такие синонимы, которые по своему значении и отношению к контексту не различаются в настоящее время совершенно. Эти синонимы называются или абсолютными, или лексическими дублетами» [12, с. 56].

Спорным является также вопрос различения абсолютных синонимов (дублетов) и вариантов слов. «Сущность варьирования, - считает Р. П. Рогожникова, - заключается в видоизменении внешней стороны слова - фонетическом или грамматическом, - не затрагивает внутренней стороны слова - его лексического значения» [10, с. 9].

Должного внимания, по нашему мнению, заслуживают научные изыскания, в которых вопрос о наличии синонимии в терминологии рассматривается в аспекте идей вариалогии $[3 ; 7 ; 10]$.

Проблема вариантности как объективный этап развития языка [3, с. 203] присутствует и в терминосистеме хореографии.

Фактический материал, извлеченный из словаря танцевальных терминов [1], специальной литературы по хореографии [2;5] демонстрирует в терминологии хореографического искусства широкое представление фонематической, морфолого-словообразовательной и лексической вариативности.

Так, фонетическая (фонематическая) вариантность, возникшая в результате действия внешних факторов (например, вследствие различной графической передачи заимствованных терминов или иноязычных морфем) представлена в наблюдаемой терминологии такими рядами вариантов:

1) варианты, различающиеся мягкой-твердой согласной фонемой: чарльстон - чарлстон; риль - рил; жоㄸ - жог; фарандола фарандоль;

2) варианты, в которых имеется различное количество фонем: cmen тэп; алеман - альман; канарис - канари; вербункош - вербунк;

3) варианты с различием в гласных фонемах: кекуок - к羊куок;

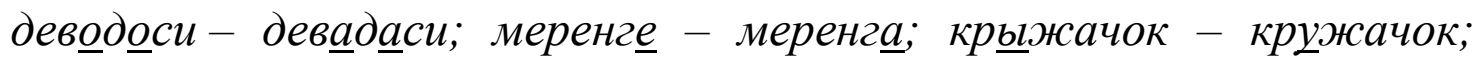
коломицйка - коломийка; тордион - турдион; форлана - фурлана; мореска-мориска; гюль-ойин - гюль-уцйин;

4) варианты, которые различаются и количеством, и качеством фонем: эстампи - эстампа - эстампида; монферрина - монфрина монфреда - манфредина; буллерия - булериас; молдавеняска мулдуванска. 
Подчеркнем, что фонематические варианты представляют собой видоизменения звуковой стороны наименований, лексическое значение терминов при этом не изменяется.

Морфологические и словообразовательные варианты представлены немногочисленными примерами: мюзет - мюзетта; тюник - тюника (замещение касается категории рода); выброс ноги - выброс ног (изменение числа); вихилясник - выхиляс (суффикс - нуль суффикса); юрачка - юрка, брейк - брейкданс (различие в способе словообразования: простое слово - сложное слово).

Вариантные синтаксические отношения в хореографической терминосистеме возникают между терминами и терминологическими сочетаниями, проявляясь в двух разновидностях:

1) термин - слово - термин - словосочетание: бокаверо - венгерский ключ; слоуфокс-медленньй фокстрот; танго - аргентинский вальс; дорожка-променад - вальсовая дорожка; джаз-танеи - джазовый танеи; алеман (альман) - вальс втроем;

2) термин - словосочетание - термин - словосочетание: восточный танеи - танеи живота; ритмопластический танец - свободный танеи; пляска смерти - данс макабр.

Среди лексических вариантов выделяются следующие ряды:

- заимствованный термин - русский термин: тетовазо - венгерский ход; боказо - венгерское заключение; мулине - фигура креста; па курю - легкий бег (легки бег);

- заимствованный термин - заимствованный термин: лур - жига (джига); брейк-брейкданс;

- русский термин - русский термин: звонок - предупреждение (одно из дробных движений испанских танцев фламенко); круг - большой танеи (старинный французский танец хороводной формы, в котором исполнители образуют два круга - внутренний и внешний); бытовой шаг - обычный шаг; скользящий шаг - шаркающий шаг;

- современный термин - устаревший термин: танщовщик (танцовщица) кордебалета - корифей (корифейка) кордебалета; оркестровое вступление (к операм и балетам) - интрада; пианист аккомпаниатор - тапер;

- исконный термин - профессиональный термин: гребень - прочес; батри -заноски.

Устаревшие и профессиональные слова, не различаясь оттенками значения и лексической сочетаемостью, все же имеют некоторую стилистическую окраску, поэтому вряд ли они образуют дублеты с исконными и заимствованными наименованиями. Перечисленные лексические варианты имеют совпадающую мотивированность, одинаковую внутреннюю форму, называют один и тот же денотат по одинаковым признакам (наименования танцев, движений, фигур, лиц). Эти термины 
настолько близки, что «практически представляют функционально одну единицу, хотя и являются разными словами. Каждое слово может быть представлено в этой связи как семантически тождественное самому себе...» [8, с. 18], т. е. являются дублетами, которым свойственна функция замещения.

В современную эпоху происходит взаимодействие и взаимовлияние разных отраслей науки, техники, искусства, что способствует формированию многозначности, и один и тот же термин используется в разных терминологиях языка.

В лингвистической литературе еще нет четкого ответа на вопрос, что же представляют собой такие термины: либо это одно слово с развитой системой значений, либо это разные слова с одинаковым значением.

Трудности возникают при решении вопроса о различении полисемантического слова и нового слова - омонима семантического образования. Вопрос этот при более внимательном рассмотрении оказывается спорным, т. к. семантические связи у многозначных слов не утрачиваются полностью, и это дает основание лингвистам относить это явление к многозначности [4, с. 71]. Однако многие языковеды использование одного и того же термина в разных терминологиях причисляют к омонимии, определяя ее как «международную терминологическую омонимию» $[4$, с. 111]. Э. И. Ханпира считает, что в таких случаях мы имеем дело с междисциплинарной (или межотраслевой) омонимией, которая возникает по двум причинам: во-первых, тогда, когда в близких или далеких друг от друга терминологиях в разное время и независимо друг от друга различные понятия приписывают одному и тому же слову; во-вторых, когда одна терминология заимствует термины у другой $[11$, с. 14]. Так, первой причиной можно объяснить существование одних и тех же терминов (сюита, сюжет, пантомима, этюд, пластика, улитка и т. п.) в двух-трех терминологиях. Ср.: Миниатюра 1. В средневековых рукописях небольшие жнивописные украшения и иллюстрации из мини (киновари); 2. Небольшая музыкальная пьеса; 3. Небольшой танцевальный номер [1, с. 174].

Благодаря второй причине распространяются в различных терминологиях так называемые «привлеченные термины» [11, с. 14]: арка, колонна, квадрат, винт, адажио, аллегро и т. д. Например: винт движение украинского народного танцуа [1, с. 60] или квадрат ${ }^{1}$ - в бальной хореографии наименование схемь шагов, образующей квадрат [1, с. 121].

Омонимия представлены в танцевальной лексике не всеми своими разновидностями: очень редко встречается омонимия терминов, возникающая в результате случайного совпадения слов в звуковом и графическом комплексах. Так, случайно общеупотребительное слово сон совпало с заимствованным танцевальным термином сон: сон (ucn. son звук, звучание) - кубинский народный танец-песня, известный с XVI века и 
после ряда трансформаџий получивший особую популярность в 20-30-х годах ХХ века [1, с. 258].

Характерной особенностью лексики хореографического искусства является то, что она обогащается в результате метафорического переосмысления одного из значений семантической структуры общеупотребительного слова. В исследуемой терминологии фиксируем большое количество терминов, которые возникли в результате метафорического переноса: 1) по сходству формы объекта или явления реальной действительности и соответствующего танцевального движения, фигуры, позы; 2) выполняемой функции; 3) по сходству формы и функции.

В первой группе метафоризируются существительные, обозначающие предметы быта, постройки, продукты питания, явления природы: беседка, ворота, восьмерка, гриб, звезда, звездочка, зигзаг, змейка и др. Ср.: корзиночка - одна из фигур хоровода, переплетенный круг, образующийся из двух кругов (круг в круге) [1, с. 135]; кувшин - одна из поз египетского танца, имитирующая держание кувшина на голове [1, с. 143].

Вторая группа более многочисленна и представлена существительными определенного действия, а также словами, называющими предметы быта, овощи, животных, птиц: бычок, бульба, бигунеи, воробей, волна, дробь, качалка, ключ, ковырялочка, кочан, кравчик, лягушка, метелка, молоточки, моталочки, мяч, переборы, перепляс, переступ, перехватка, печатка, плетение, подсекач, подскок, позировка, ползунок, припляс, притоп, разножка, ручеек, тройка, тряска, хлопушка, шевчик, штопор. Ср.: хлопушка - движение русского народного танца, исполняемое мужчинами. Представляет собой удары ладонями или ладонью по голенищу сапога, по подошве, возле колена ноги и по плечам $[1$, c. 306]; бычок - белорусский народный молодежный танец, имитирующий движения животного [1, с. 49]. Некоторые названия народных танцев в этой группе связаны с трудовыми и профессиональными действиями человека, например: бульба (процесс посадки и сбора картофеля); кочан (земледельческий обряд посадки капусты и сбора урожая); кравчик (украинский народный танец, имитирующий движения портных); шевчик (украинский народный танец, имитирующий движения сапожников).

К третьей группе относятся существительные, обозначающие предметы быта, явления природы, названия живых существ: веер, веревочка, волчок, ключ, метелица, спираль, улитка, цепочка и др. Ср.: метелица - старинный украинский хороводный танец, для рисунка которого характерны разнообразные затейливые быстро сменяющиеся узоры [1, с. 172]; цепочка - фигура русских народных танцев. Танцующие стоят в одну линию. Первый в линии соединяет руки перед корпусом замком, следующий опускает руку через его соединенные руки и также соединяет руки замком и т. д. [1, с. 314$]$. 
Таким образом, многообразные лексико-семантические отношения на уровне парадигматики в терминологии хореографического искусства свидетельствуют об объективности, распространенности и пока что неизбежности таких явлений, как синонимия, полисемия, омонимия.

Проблема терминологических вариантов, проявляющихся на фонематическом, морфолого-синтаксическом уровнях, неразрывно связана с вопросами языковой нормы, упорядочения и усовершенствования терминосистемы.

\section{Литература}

1. Балет. Танец. Хореография : краткий словарь танцевальных терминов и понятий / Сост. Н. А. Александрова. - СПб : Изд-во «Лань» ; «Издательство Планета Музыки», 2008. - 416 с.

2. Вашкевич Н. Н. История хореографии всех веков и народов / Н. Н. Вашкевич. - СПб : Лань, 2009. - $192 \mathrm{c}$.

3. Горбачевич К. С. Вариантность слова и языковая норма / На материале современного русского языка / К. С. Горбачевич. - Л. : Наука, 1978. - 238 с.

4. Даниленко В. П. Русская терминология : Опыт лингвистического описания / Валерия Петровна Даниленко. - М. : Наука, 1977. - 246 с.

5. Зайцев Є. В. Основи народно-сценічного танцю : [навч. посібник] / Є. В. Зайцев, Ю. В. Колісниченко. - Вінниця : Нова Книга, 2007. - 416 с.

6. Кутина Л. Л. Языковые процессы, возникающие при становлении научных терминологических систем / Л. Л. Кутина // Лингвистические проблемы научно-технической терминологии. - М. : Наука, 1970. - C. 82-94.

7. Никитина Ф. А. Влияние аналогии на словообразование : На материале родственных языков / Ф. А. Никитина. - К. : Изд-во Киевского университета, 1973. - 198 с.

8. Новиков Л. А. Синонимические функции слов : Семантическая синонимия / Л. А. Новиков // Русский язык в школе. - 1968. - №1. - С. 11-23.

9. Реформатский А. А. Введение в языкознание / А. А. Реформатский. - М. : Просвещение, 1967. -542. с.

10. Рогожникова Р. П. Варианты слов в русском языке / Р. П. Рогожникова. - М. : Просвещение, 1966. $-160 \mathrm{c}$.

11. Ханпира Э. И. О терминах и терминологии / Э. И. Ханпира // Русский язык в национальной школе. - 1985. - №4. - С. 11-17.

12. Шанский Н. М. Лексикология современного русского языка / Николай Максимович Шанский. М. : Просвещение, $1972 .-327$ с.

Стаття надійшла до редакції 21.10.2011 p. 